\title{
VISUAL PERCEPTION OF URBAN GREENING IN PUBLIC PARKS: EVIDENCE FROM TRABZON CITY, TURKEY
}

\author{
Nilgun GUNEROGLU*, Makbulenur BEKAR \\ Department of Landscape Architecture, Faculty of Forestry, Karadeniz Technical University, \\ 61080 Trabzon, Turkey
}

Received 26 December 2020; accepted 30 August 2021

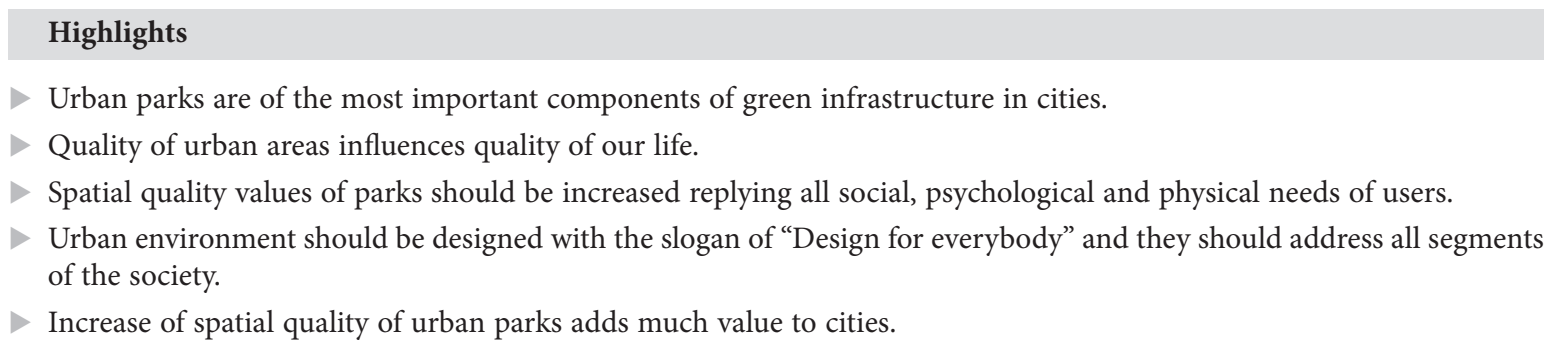

\begin{abstract}
Urban parks are of the most important components of green infrastructure in cities. Number and size of green areas decrease especially due to increase in population and urbanization. Urban parks rank first among green areas that increase and improve the quality of life in cities. Urban parks are places where people can commune with nature and spend their free time for leisure. Accessibility of urban parks, their recreational facilities and space identity are very effective on satisfaction of users. This study is about EYOF Park in Trabzon city. Visual perception analysis carried out using landscape quality criteria. User satisfaction was analyzed with statistical analyses. As a result of analysis, the highest correlations were found between "color" and "texture" $(r=0.790)$. The most important reasons of park visit was found to be for "relaxing" purposes, moreover "lack of car park" was stated as the most important problem for the park.
\end{abstract}

Keywords: urbanization, urban parks, user satisfaction, space quality.

\section{Introduction}

City phenomenon is a dynamic concept shaped from the simple to the complex context and having different meanings from the past to the present. City is a production area which comes into being with physical features and people's life, culture and economic status (Topal, 2004). Cities are meeting areas that bringing people together and make them socialize (Uzgören \& Erdönmez, 2017). Gehl (2010), on the other hand, defends city as a formation shaped according to opinions, trade, needs and wishes of people living in it. Huot et al. (2000) defines city as a settlement area with unique qualities overcoming problems that cannot be solved individually in a complex social structure. We can also define city as an organism effecting all living and non-living beings inside (Hayta \& Altan, 2016).
Success of public areas composing a city is related with being used by more people as living areas (Gürer \& Uğurlar, 2017). These areas are environments where various events have occurred from the past to present and use of which has changed according to these events (Karakurt, 2006). With the definition of İnceoğlu and Aytuğ (2009), urban areas are combinations of space status and related structural elements of the cities. In his studies on urban areas, Lynch emphasize that people use urban imagery when perceiving cities and thus these symbols have importance in creation of urban texture in their minds (Ülkeryıldız, 2009). Moreover, perception of landscape by users should not stand as qualitative statements and it needs to be converted to quantified measures or metrics in order to provide necessary scientific basis for planning of green spaces (Liu et al., 2016). Public areas provide users

*Corresponding author. E-mail: nayhan@ktu.edu.tr 
with immediate vicinity to get in contact with structural and green texture and with each other (Ostoić et al., 2017). These areas exhibit collective life forms of people. Parks, streets and squares of cities shape life of people (Bayramoğlu, 2010). Living in a good city is not only related with parameters like health, but it is also related with quality of urban areas (Wolch et al., 2014). Quality areas can heal disharmonies in a society (Şahan, 2016; Herrington, 2015). Thus, they can transform all living or nonliving resources with a process of continuous change. So, while cities change their shapes according to behaviors, needs and relationships of people, they also influence individuals directly. Cities influence individuals both socially and physically and this effect is realized via public areas. Indeed, cities are composed of different space formations. Bayramoğlu (2010) underlines that, space formation came into being with the effort to guide people in city areas like squares, streets, public areas, coasts etc.

Recently studying perception of green space by people has become an important research area due to their influential nature on well-being, comfort and health of the human. Therefore designing and providing access to such facilities has become an issue of environmental justice (Wolch et al., 2014). Urban parks are areas with the utmost use among environments of a city (Liu et al., 2016; Bahriny \& Bell 2020). It is estimated that Central Park in the USA is visited by approximately 42 million visitors every year, Golden Gate Park in San Francisco is visited by 13 million people on average and Amsterdam Volden Park attracts 10 million tourists each year (Central Park Conservancy, 2018; San Francisco Recreation and Parks, 2018; Vondel Park, 2018). The most important parameters justifying preference of these parks are their recreational varieties, quality, ecological and aesthetic features. These parameters are very important to attract people to parks and make them spend time there (Zhang \& Zhou, 2018). Comfort of parks is directly related with their variety in seasonal changes, selection of facilities and design decisions in the plans (Jahani \& Saffariha, 2020). Designing and documenting of accessibility and safety criteria are also important parameters for parks or public areas (Wey \& Wei, 2016; Santos et al., 2016). Dealing with safety in urban parks can also prevent some negative effects such as crime and vandalism (Bahriny \& Bell, 2020). Besides these parameters, urban park designs should be implemented in accordance with city plans by considering color, size and texture that shape the city character (Carmona et al., 2003). These are important steps to achieve strategic management of green parks (Santos et al., 2016). Quality of urban areas influences quality of our life (Polat \& Akay, 2015). Citizens are users of the city when they spend time out of their homes, whatever their economic status or life style is. Rapoport (1977) defines urban area quality as the factor revealing difference in design and as the most important factor creating selective perception. Having carried out various studies on quality of urban areas, Gibson (1979) states that noticeable differences and details can be observed in space quality. Lynch (1973) defends that there are five basic theories for formation of a good city and a quality urban area including healthy environment, space-identity feeling, space adaptation, access to activities, people, areas and information and control of environmental responsibility. Gehl (1987) defines the relationship between urban area activities and quality of physical area under three titles as necessary activities, optional activities and social activities. He defends that these three urban area activities show different dependencies to the physical environment. A non-profit institution in the United States of America, named Project for Public Spaces, working on planning, design, education and research, states that the factors making a space perfect are transportation from the location to other important areas and ease of access, being comfortable or not, providing facilities for various recreative activities and the potential to create demand to visit again and again (Project for Public Spaces [PPS], 2005). People's perception of green space including parks and related amenities is very important in terms of social impacts of landscaping. Furthermore, knowing the people's perception and aesthetic preferences can greatly contribute to create and maintain better city environments by the decision makers or public authorities (Ostoić et al., 2017). As urban parks are widely used by citizens and visitors of cities, they are the most important areas where space quality has to be created. Space quality values of parks should be increased replying all social, psychological and physical needs of users. Therefore, the aim of this study is to determine user satisfaction of Trabzon EYOF (European Youth Olympic Festival) Memory Park in terms of space quality parameters. The research question on "Which space quality parameters are the most effective for visitors" was envisaged. Relationships between user satisfaction and space quality were examined statistically and the most effective parameters were determined.

\section{Material and method}

\subsection{Material}

Study was carried out at Eastern Black Sea Region, Trabzon city, EYOF 2011 Sport Memory Park. Trabzon city has an area of $4.664 \mathrm{~km}^{2}$, is located between $38^{\circ} 30^{\prime}-40^{\circ} 30^{\prime}$ East meridians and $40^{\circ} 30^{\prime}-41^{\circ} 30^{\prime}$ North parallels. It has Rize city in the east, Giresun in the west, Bayburt-Gümüşhane in the South. It is a coastal city facing Black Sea in the Northern side (Dihkan et al., 2017). EYOF Memory Park, which is the main material of this study, is in Trabzon Ortahisar District Kalkınma Neighborhood, in the south of Forum Shopping Centre and located on state coastal road on an area of 30.000 square meters (Figure 1).

EYOF Memory Park was founded in order to cherish the memory of 11th European Youth Olympics which was held in Turkey for the first time. 49 trees, representing countries attending European Youth Olympics, were planted in the park and an identification tag was fixed to each of them. Park has elements reflecting Ottoman garden concept and Japanese garden art as well (Figure 2). 


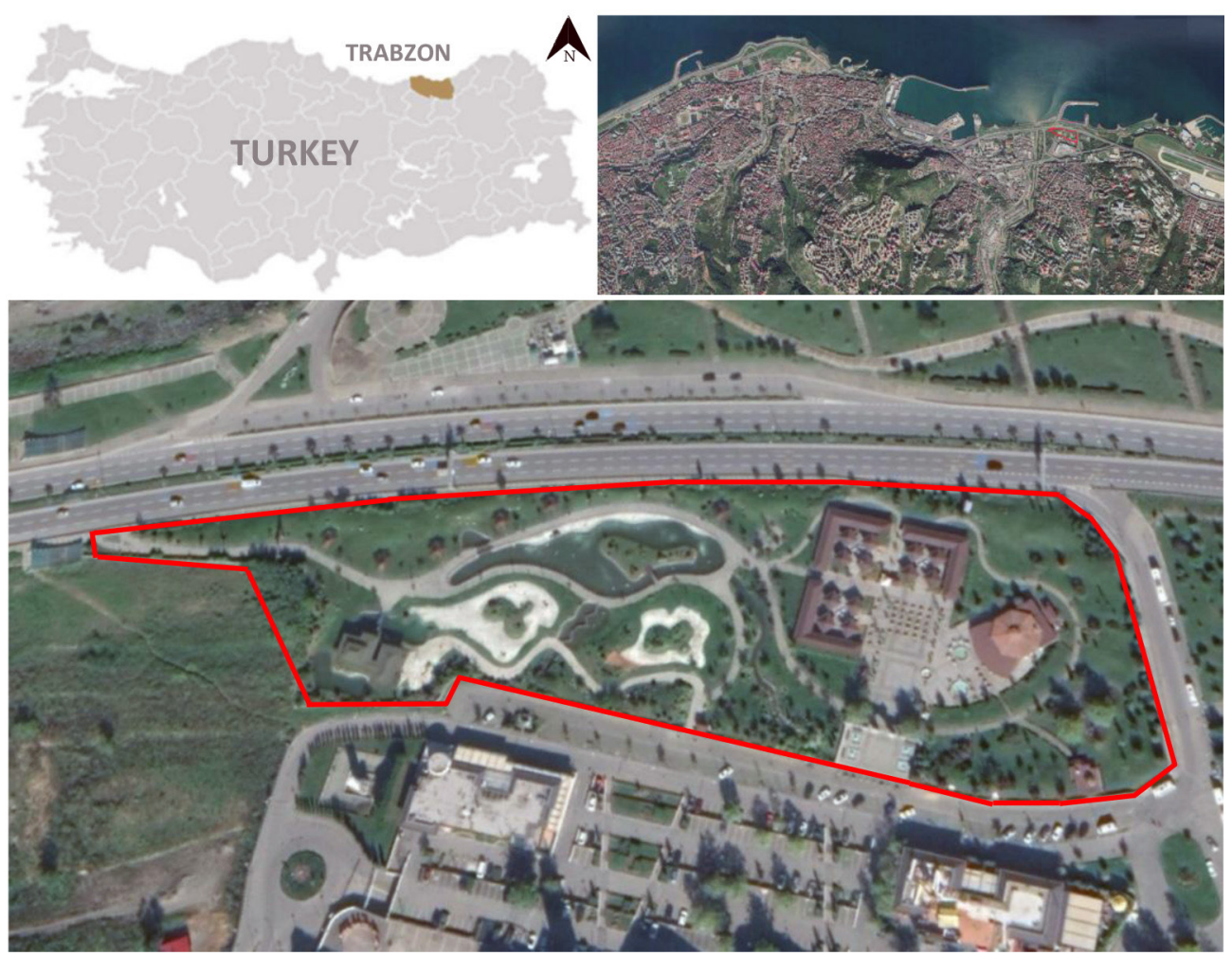

Figure 1. Study area

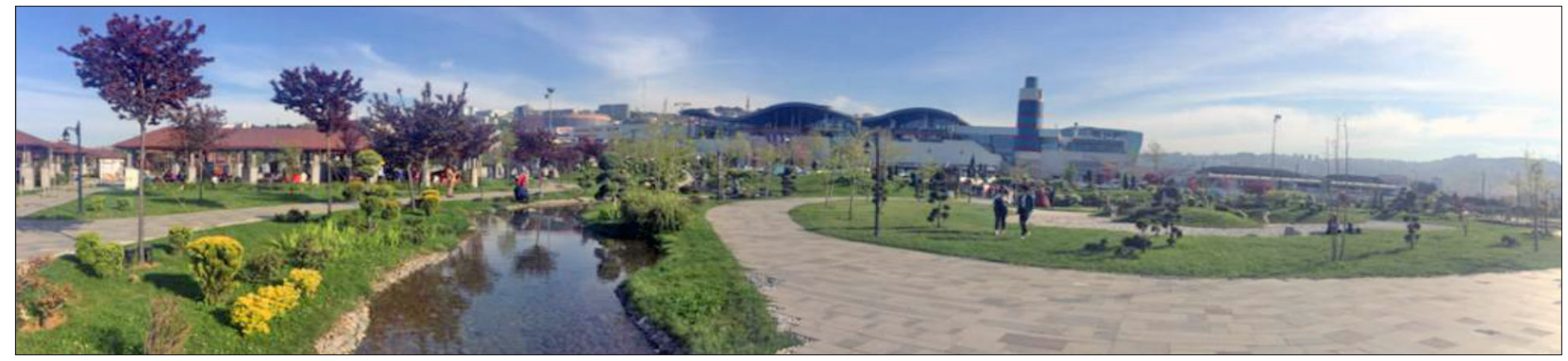

Figure 2. Panoramic view of the park

Shaped with garden features of two cultures, the park adds an important value to the city in terms of aesthetic, functional and ecological contexts.

EYOF Memory Park is located on the Eastern Black Sea coastal road route and is 200 meters away from Forum Shopping Centre, the biggest shopping area of Trabzon city. Its closeness to the shopping center is one of the factors that users preference of the park. Especially green areas, water element, facilities and the service increase use of the park by the citizens. Besides, the park has many recreation facilities for short term needs of users in the daily life like resting, sitting, watching, walking, eating etc. The park is used for enjoying aesthetic appearances with seasonal changes, taking photos, wedding organizations, games and watching the landscape (Figure 3 ).

\subsection{Method}

The study is composed of three phases. At the first phase purposes and area limits of the study were determined. At the second phase, data was obtained. And at the last phase questionnaires were done in order to determine space quality and user satisfaction of the park. The study aims to quantify user perceptions and satisfactions of the park in order to derive the overall space quality based on the current condition and facilities. The relationship between space quality and user satisfaction was discussed according to data determined from questionnaires (Figure 4).

Questionnaires of the study are composed of 3 parts. The first part was prepared to determine demographic features of users, the second part was prepared to determine space quality of the area and the third part was prepared in order to find values for user satisfaction (Figure 5). Parameters used in the second phase of study were selected from those used in the literature for determination of space quality and they are examined with questions appropriate to five main titles which are "accessibility and connections", "comfort and aesthetics", "possibility of recreation", "social effects" and "feeling of space identity". 


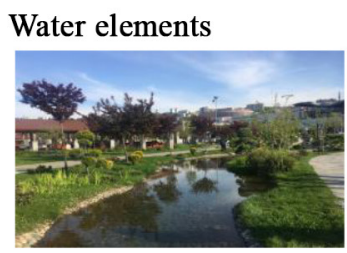

Cover elements

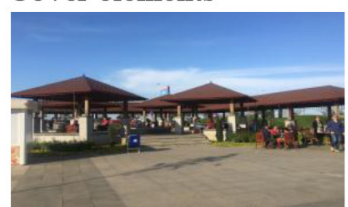

Walkig track

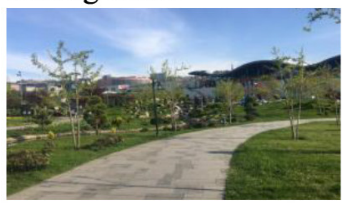

Zen garden

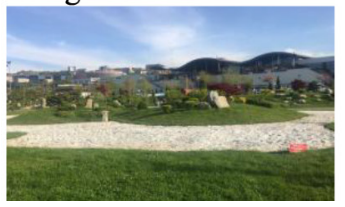

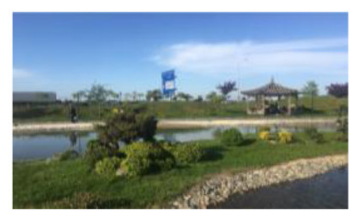
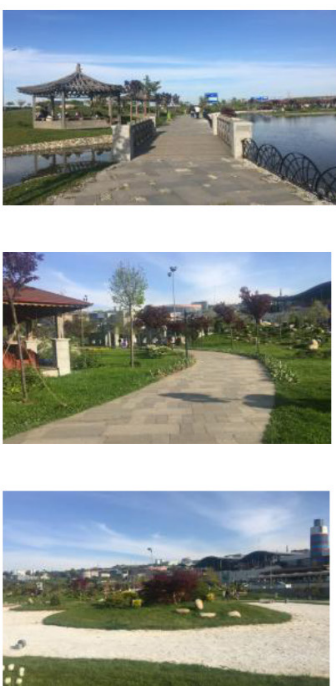

Seating units
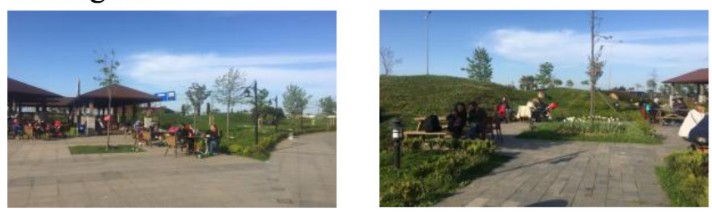

Eating and drinking establishment

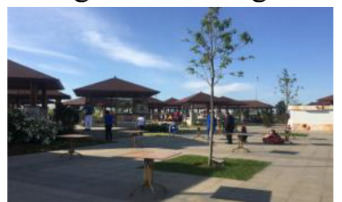

Planting compositions

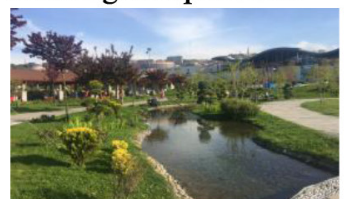

Coffee shop

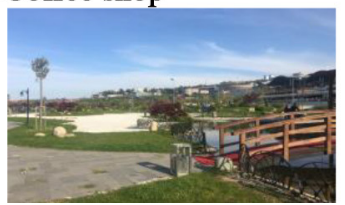

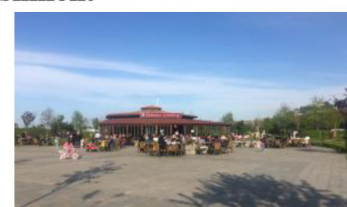
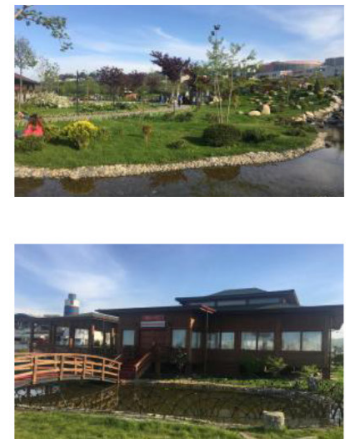

Figure 3. EYOF Memory Park activity areas and qualities of the space

Moreover, these main titles can be further differentiated to 29 parameters (beautiful, impressive, unique, accessible, readable, comfortable, relaxing, restful, safety, well-kept, recreative, memorable, color, texture, size, shape, line, perceptible, diversity, complexity, unity, continuity, four seasons, life quality, economic contribution, city identity, all people, furniture, liking) as explained by many researchers

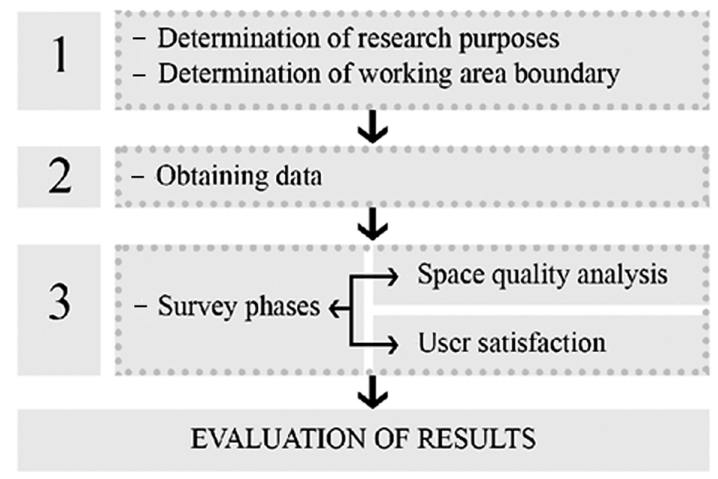

Figure 4. Phases of the study in literature (Lynch, 1973; Rapoport, 1977; Gibson, 1979; PPS, 2005; Gehl, 1987; Gehl \& Gemzøe, 2001). This study pursued similar methodology to obtain space quality of EYOF Memory Park. Clear questions were asked in order to find the most preferred parameter by the visitors and users of the park. All parameters were questioned with 29 statements and evaluated with 5 degree "Likert Attitude Scale". The questions were scored with 5 degree evaluation scale such as "Certainly agree", "Agree", "No idea", "Disagree", "Certainly disagree" by visitors or users $(N=100)$. Approximately 15 minutes were spent with each user for questionnaire interviews.

Questionnaires were evaluated and parameters defining space quality of the park were determined statistically. At first step, space quality analyses were carried on by researching the available literature on space quality evaluation as explained in Figure 5. Finally user evaluations were collected for all 29 quality parameters with 29 questions. Obtained data was first analyzed for normalization by using descriptive statistics of normal distribution by

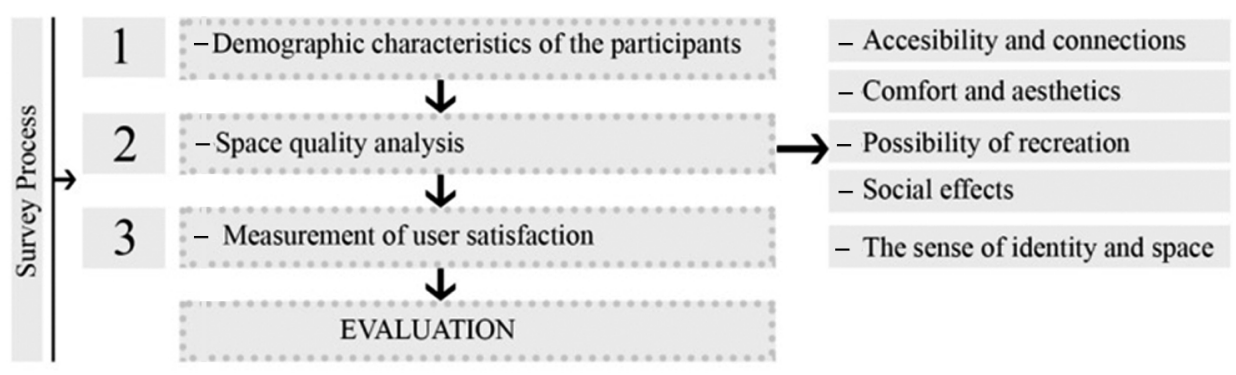

Figure 5. Conceptual framework of the study 
SPSS 23.0 software. For simplicity of the problem design and space quality parameters were separately evaluated as shown in Tables 2 and 3 . Testing the normality of data could greatly affect the overall quality of the next statistical analyses. Moreover correlation analyses were applied to find the most correlated parameters as given in Table 4. Finally factor analyses were calculated to decide on the most effective factors groups and their related parameters. Factor analysis is a statistical approach providing new variants with grouping parameters in a study monitored with multiple parameters. Space quality and user satisfaction were examined by measuring preferability of the area by evaluation of users with the determined parameters. Multiple choice questions were prepared for determination of user satisfaction. Questionnaires included questions on distance of the park to the place where user came from, frequency of visit, purpose of visit, recreational facilities, the service given, transportation and car park facilities and problems in the park. Results of questionnaires were numbered and numerical results were obtained and evaluated as percentages in Tables through 6 to 10 .

\section{Findings}

This research examined EYOF Memory Park in Trabzon city. Targets of the park on meeting space quality expectations and being a part of the city appropriate to user satisfaction were derived as a result of questionnaires. Findings of examinations are given below.

\subsection{User profile}

Findings on characteristics of people participating in the research (age, gender, marital status, educational status, working status, income level) are given in Table 1. According to Table 1, 43 participants were "male" and 57 were "female". 63 of them were "married" and 37 were "single". 30 participants were "officers", 28 were "over the age of 40 " and 40 were "university graduate".

\subsection{Findings according to quality parameters}

Considering the current study, quality parameters were envisaged as a combination of design elements and space quality parameters. This is because of design elements are accepted as fundamental basis of landscape projects and all other parameters are complementary part in designs. Design elements such as color, texture, size, shape, line are given importance in order to provide space perception in landscape designs. Integrity of structures and plants with each other and the area is provided with design elements. The study used descriptive normality analyses and correlation matrix to find whether there is a statistically meaningful relationship between these elements in perception of the park. When results of the test are considered, it is determined that all measured parameters were normally distributed as shown in Table 2 and Table 3.
Table 1. Social-demographical status of users

\begin{tabular}{|c|c|c|c|c|c|}
\hline $\begin{array}{l}\text { Vari- } \\
\text { ables }\end{array}$ & & Frequency & Variables & & $\begin{array}{c}\text { Fre- } \\
\text { quency }\end{array}$ \\
\hline \multirow{3}{*}{$\begin{array}{l}\text { Gen- } \\
\text { der }\end{array}$} & Mr. & 43 & \multirow{3}{*}{$\begin{array}{l}\text { Marital } \\
\text { status }\end{array}$} & Married & 63 \\
\hline & Mrs. & 57 & & Single & 37 \\
\hline & Total & 100 & & Total & 100 \\
\hline \multirow{7}{*}{ Age } & $15-20$ & 7 & \multirow{7}{*}{$\begin{array}{l}\text { Education } \\
\text { level }\end{array}$} & Uneducated & - \\
\hline & $20-25$ & 15 & & $\begin{array}{l}\text { Primary } \\
\text { school }\end{array}$ & - \\
\hline & $25-30$ & 25 & & $\begin{array}{l}\text { Middle } \\
\text { School }\end{array}$ & 5 \\
\hline & $30-35$ & 9 & & $\begin{array}{l}\text { High } \\
\text { school }\end{array}$ & 30 \\
\hline & $35-40$ & 16 & & University & 40 \\
\hline & $40+$ & 28 & & Graduate & 25 \\
\hline & Total & 100 & & Total & 100 \\
\hline \multirow{7}{*}{ Job } & $\begin{array}{l}\text { Unem- } \\
\text { ployed }\end{array}$ & 3 & \multirow{7}{*}{$\begin{array}{l}\text { Income } \\
\text { status }\end{array}$} & No income & 25 \\
\hline & Student & 26 & & $500-1000$ & 6 \\
\hline & Officer & 30 & & $1000-2000$ & 4 \\
\hline & Worker & 8 & & $2000-3000$ & 20 \\
\hline & $\begin{array}{l}\begin{array}{l}\text { House- } \\
\text { wife }\end{array} \\
\end{array}$ & 15 & & $3000-4000$ & 17 \\
\hline & Others & 18 & & $4000+$ & 28 \\
\hline & Total & 100 & & Total & 100 \\
\hline
\end{tabular}

Table 2. Normality results of design elements scoring average

\begin{tabular}{|c|c|c|c|c|c|c|}
\hline \multirow{5}{*}{ 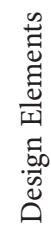 } & \multicolumn{3}{|c|}{ Test of Normality } & \multicolumn{3}{|c|}{ Kolmogorov-Smirnov } \\
\hline & & Statistic & Std. Error & Statistic & $\mathrm{df}$ & Sig \\
\hline & Mean & 3.686 & 0.086 & \multirow{3}{*}{0.086} & \multirow{3}{*}{100} & \multirow{3}{*}{0.67} \\
\hline & Skewness & -0.247 & 0.241 & & & \\
\hline & Kurtosis & -0.120 & 0.478 & & & \\
\hline
\end{tabular}

The same analyses were carried out for space quality parameters which are as follow beautiful, impressive, unique, accessible, readable, comfortable, relaxing, restful, safety, well-kept, recreative, memorable, perceptible, diversity, complexity, unity, continuity, four seasons, life quality, economic contribution, city identity, all people, furniture and liking. The given scores for space quality parameters were also normally distributed. This can be inferred from normality statistics according to George and Mallery (2020).

Table 3. Normality results of space quality parameters scoring average

\begin{tabular}{|c|c|c|c|c|c|c|}
\hline \multirow{5}{*}{ 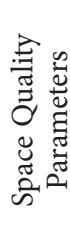 } & \multicolumn{3}{|c|}{ Test of Normality } & \multicolumn{3}{|c|}{ Kolmogorov-Smirnov } \\
\hline & & Statistic & Std. Error & Statistic & $\mathrm{df}$ & Sig \\
\hline & Mean & 3.741 & 0.067 & \multirow{3}{*}{0.076} & \multirow{3}{*}{100} & \multirow{3}{*}{0.160} \\
\hline & Skewness & -0.304 & 0.241 & & & \\
\hline & Kurtosis & 0.205 & 0.478 & & & \\
\hline
\end{tabular}




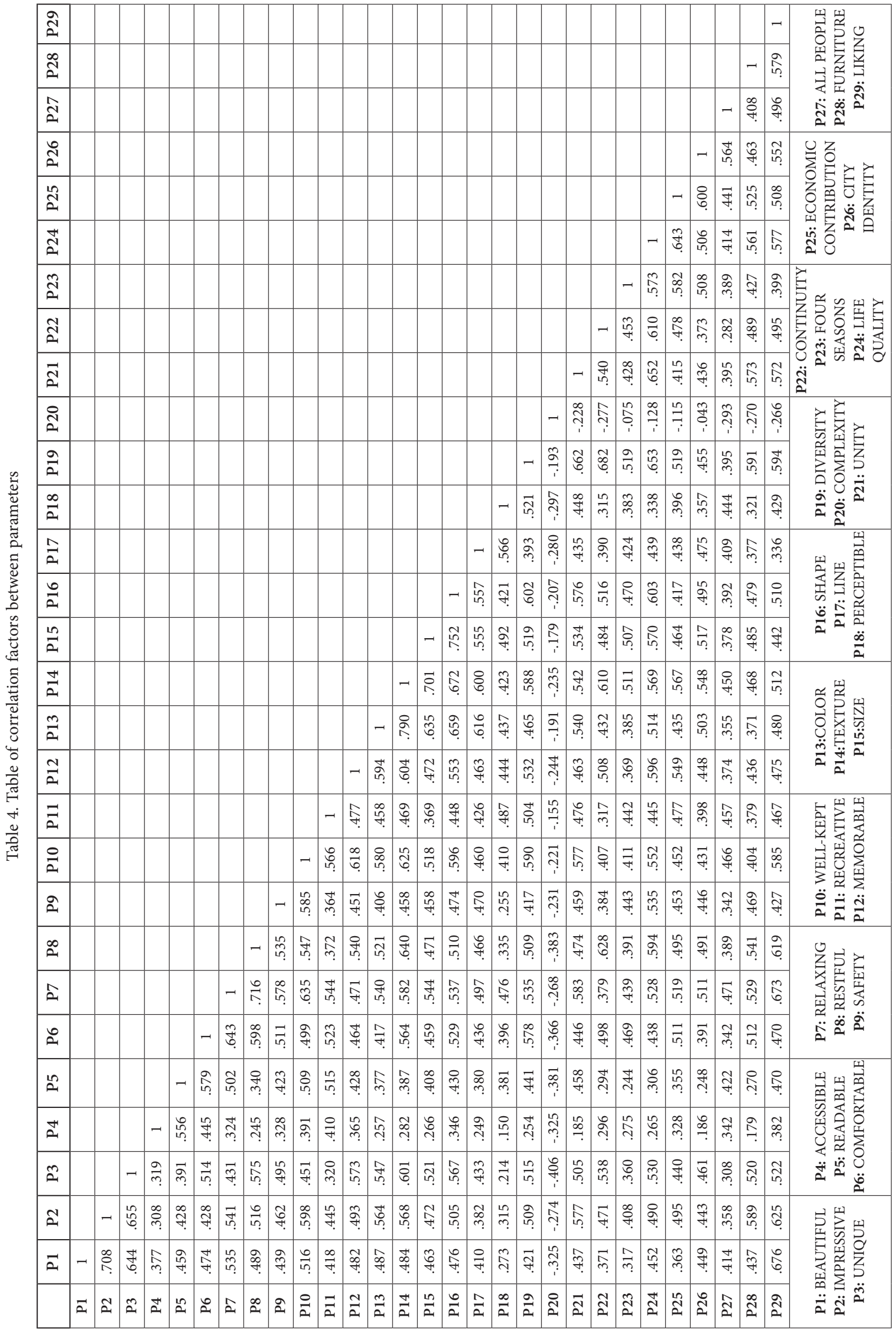


Relationships between quality parameters were determined by applying correlation analyses. Pearson correlation factors were calculated at $99 \%$ importance level. As a result of analysis, the highest correlations were found between "color and texture" $(r=0.790, p<0.01)$ and, "size and shape" $(r=0.752, p<0.01)$. Similarly, relatively high correlations were observed between "relaxing and restful" $(r=0.716, p<0.01)$ "impressive and beautiful" $(r=0.708$, $p<0.01)$. Besides, meaningful values were also determined between "texture and size" $(r=0.701, p<0.01)$. Correlation matrix is given in Table 4 .

Statistical results of factor analyses were used to determine the most effective factors on space quality. Six effective components were found for revealing space quality with basic factor analysis (Table 5). According to analysis results, the first factor, which explains $49.7 \%$ of the total variance, consist of "economic contribution", "city identity", "four seasons effect", "life quality", "restful”, "furniture", "safety", "complexity" parameters. "Color", "line”, "texture", "size", "shape", "memorable" and "well-kept" parameters explained $5.6 \%$ of the total variance as the second factor. Briefly, two first components revealed more than $50 \%$ of the total variance. This means that parameters given in bold character belonging to factors " 1 " and " 2 " in Table 5 are the most influential parameters shaping the preferences of the park visitors. Furthermore, the total explained variance is $71 \%$ after the analyses with 6 factors. Summarized factor analyses results were given in Table 5.

\subsection{User satisfaction}

Concept of the park was designed as Turkish-Japanese garden as appropriate to its foundation purpose. When participants' awareness of this concept was questioned, $41 \%$ answered as "yes", 15\% answered as "no", 30\% answered as

Table 5. The most effective parameters of space quality revealed by factor analyses

\begin{tabular}{|c|c|c|c|c|c|c|c|}
\hline \multirow{2}{*}{ Parameters } & \multicolumn{6}{|c|}{ Factors } & \multirow{2}{*}{$\begin{array}{l}\text { Common } \\
\text { Variance }\end{array}$} \\
\hline & 1 & 2 & 3 & 4 & 5 & 6 & \\
\hline Economic contribution & .788 & .209 & .138 & .185 & .157 & .113 & 0.75 \\
\hline City identity & .671 & .389 & .248 & .101 & .140 & -.128 & 0.70 \\
\hline Four seasons & .667 & .273 & .054 & .089 & .248 & .098 & 0.60 \\
\hline Life quality & .649 & .223 & .312 & .021 & .344 & .237 & 0.74 \\
\hline Restful & .535 & .306 & .384 & .203 & .060 & .328 & 0.68 \\
\hline Furniture & .486 & .073 & .455 & .011 & .330 & .342 & 0.67 \\
\hline Safety & .486 & .296 & .312 & .350 & -.076 & .161 & 0.57 \\
\hline All people & .411 & .269 & .238 & .334 & .340 & -.059 & 0.52 \\
\hline Complexity & .106 & -.179 & -.151 & -.401 & -.077 & -.657 & 0.66 \\
\hline Color & .160 & .820 & .305 & .139 & .126 & .044 & 0.82 \\
\hline Line & .282 & .739 & .123 & .130 & .146 & .166 & 0.70 \\
\hline Texture & .398 & .676 & .274 & .136 & .146 & .227 & 0.78 \\
\hline Size & .323 & .674 & .235 & .119 & .280 & .165 & 0.73 \\
\hline Shape & .220 & .612 & .280 & .243 & .293 & .204 & 0.68 \\
\hline Memorable & .331 & .466 & .218 & .316 & .146 & .287 & 0.57 \\
\hline Well-kept & .241 & .443 & .437 & .371 & .291 & .037 & 0.66 \\
\hline Beautiful & .155 & .289 & .777 & .271 & .075 & .104 & 0.80 \\
\hline Impressive & .179 & .271 & .738 & .173 & .183 & .174 & 0.74 \\
\hline Liking & .372 & .158 & .598 & .212 & .397 & .133 & 0.74 \\
\hline Unique & .286 & .336 & .561 & .163 & -.012 & .510 & 0.79 \\
\hline Relaxing & .398 & .295 & .456 & .371 & .300 & -.001 & 0.68 \\
\hline Accessible & .139 & .111 & .118 & .831 & -.026 & .165 & 0.76 \\
\hline Readable & .055 & .181 & .255 & .742 & .319 & .138 & 0.77 \\
\hline Comfortable & .438 & .184 & .190 & .534 & .199 & .331 & 0.69 \\
\hline Perceptible & .140 & .538 & -.049 & .141 & .654 & .126 & 0.77 \\
\hline Diversity & .379 & .173 & .200 & .137 & .654 & .371 & 0.79 \\
\hline Unity & .248 & .223 & .428 & .093 & .636 & .170 & 0.73 \\
\hline Recreative & .263 & .299 & .234 & .429 & .491 & -.105 & 0.65 \\
\hline Continuity & .401 & .196 & .140 & .052 & .283 & .684 & 0.77 \\
\hline Variance (\%) & 49.7 & 5.6 & 4.6 & 3.9 & 3.8 & 3.4 & 71 \\
\hline
\end{tabular}


"I learned here", and 15\% answered as "no opinion". Again, when participants' awareness of park's foundation for European Youth Olympics was questioned, $45 \%$ "yes", $25 \%$ "I learned here", 13\% "no" and 17\% "no opinion" values were given in Table 6 .

According to questions on park usage choices, the results were as follows: $46 \%$ of participants came to park "every week", $53 \%$ "at the weekends", $64 \%$ of participants came from " $5-10 \mathrm{~km}$ " away, $48 \%$ visited in "summer", $62 \%$ spent " $1-2$ hours" at the park, $64 \%$ came to park in groups of " $3-5$ persons" and $53 \%$ came to park with "friends" and purpose of visit of $65 \%$ was not related with Forum Shopping Centre (Table 7).

Table 6. Data on public awareness of the park

\begin{tabular}{|c|c|c|c|}
\hline \multicolumn{4}{|c|}{$\begin{array}{c}\text { Do you know that this park has a concept that reflects } \\
\text { Turkish and Japanese gardens? }\end{array}$} \\
\hline Variables & Percent (\%) & Variables & Percent (\%) \\
\hline Yes & 41 & No & 14 \\
\hline I learned here & 30 & No opinion & 15 \\
\hline \multicolumn{4}{|c|}{$\begin{array}{c}\text { Do you know that this park was built for the 11th European } \\
\text { Youth Olympics? }\end{array}$} \\
\hline Variables & Percent (\%) & Variables & Percent (\%) \\
\hline Yes & 45 & No & 13 \\
\hline I learned here & 25 & No opinion & 17 \\
\hline
\end{tabular}

Table 7. Park usage choices

\begin{tabular}{|c|c|c|c|}
\hline \multicolumn{4}{|c|}{ Frequency of arrival to the park } \\
\hline Variables & Percent $(\%)$ & Variables & Percent (\%) \\
\hline Everyday & - & Rarely & 12 \\
\hline Every other day & 38 & $\begin{array}{l}\text { First time I } \\
\text { came }\end{array}$ & 4 \\
\hline Every week & 46 & & \\
\hline \multicolumn{4}{|c|}{ Time to park } \\
\hline Variables & Percent $(\%)$ & Variables & Percent (\%) \\
\hline Weekend & 53 & $\begin{array}{l}\text { When I came } \\
\text { to Forum } \\
\text { Shopping } \\
\text { Center }\end{array}$ & 18 \\
\hline Weekdays & 29 & & \\
\hline \multicolumn{4}{|c|}{ Distance to the park } \\
\hline Variables & Percent $(\%)$ & Variables & Percent (\%) \\
\hline $1-5 \mathrm{~km}$ & 20 & $10-20 \mathrm{~km}$ & 9 \\
\hline $5-10 \mathrm{~km}$ & 64 & $+20 \mathrm{~km}$ & 7 \\
\hline \multicolumn{4}{|c|}{$\begin{array}{l}\text { Are you coming to this park when you came to the Forum } \\
\text { Shopping Center? }\end{array}$} \\
\hline Variables & Percent $(\%)$ & Variables & Percent (\%) \\
\hline Yes & 13 & Almost & 14 \\
\hline No & 65 & No opinion & 8 \\
\hline \multicolumn{4}{|c|}{ Which season is your most used this park? } \\
\hline Variables & Percent $(\%)$ & Variables & Percent (\%) \\
\hline Spring & 44 & Autumn & 4 \\
\hline Summer & 48 & Winter & 4 \\
\hline
\end{tabular}

End of Table 7

\begin{tabular}{|c|c|c|c|}
\hline \multicolumn{4}{|c|}{ How much time do you spend in this park? } \\
\hline Variables & Percent $(\%)$ & Variables & Percent (\%) \\
\hline $1-2$ hours & 62 & +5 hours & 3 \\
\hline $3-5$ hours & 35 & & \\
\hline \multicolumn{4}{|c|}{ How many people do you come to this park? } \\
\hline Variables & Percent (\%) & Variables & Percent (\%) \\
\hline Alone & 1 & 6-10 people & 8 \\
\hline 2 people & 21 & 11-15 people & 1 \\
\hline 3-5 people & 64 & +16 & 5 \\
\hline \multicolumn{4}{|c|}{ Who are you coming to this park? } \\
\hline Variables & Percent (\%) & Variables & Percent (\%) \\
\hline Family members & 47 & Friends & 53 \\
\hline
\end{tabular}

The most important reasons of park visit were for "relaxing" $12 \%$, "silence and peace" $9 \%$, "to be close nature" $9 \%$, "for clean air" 9\%, "for taking photos" $8 \%$, "to learn the concept of park" $8 \%$ (Table 8).

Table 8. Purpose of park visit

\begin{tabular}{|c|l|c|c|}
\hline No & \multicolumn{1}{|c|}{ The purpose of arrival } & $\begin{array}{c}\text { Fre- } \\
\text { quency } \\
(\mathrm{f})\end{array}$ & $\begin{array}{c}\text { Rate } \\
(\%)\end{array}$ \\
\hline 1 & Reading books & 8 & 1 \\
\hline 2 & Relaxing & 73 & 12 \\
\hline 3 & Hiking & 43 & 7 \\
\hline 4 & Silence and peace & 56 & 9 \\
\hline 5 & Meeting new people & 5 & 1 \\
\hline 6 & Seeing different landscapes character & 9 & 1 \\
\hline 7 & To experience adventure and joy & 7 & 1 \\
\hline 8 & Eating food & 9 & 1 \\
\hline 9 & $\begin{array}{l}\text { For game possibilities (skateboard, } \\
\text { kite ... etc.) }\end{array}$ & 5 & 1 \\
\hline 10 & For tea garden & 45 & 7 \\
\hline 11 & For taking photos & 46 & 8 \\
\hline 12 & To be close to nature & 54 & 9 \\
\hline 13 & To see planting compositions & 6 & 1 \\
\hline 14 & To learn the concept of park & 50 & 8 \\
\hline 15 & For doing exercise & 5 & 1 \\
\hline 16 & For fresh air & 54 & 9 \\
\hline 17 & For staying self-sit & 14 & 2 \\
\hline 18 & For group fun & 613 & 7 \\
\hline 19 & For a picnic & 70 \\
\hline 20 & For making the barbecue & 7 \\
\hline 21 & For children's playgrounds & 6 \\
\hline & Total & 5 & 6 \\
\hline & & 5 & 1 \\
\hline
\end{tabular}

According to participants, $90 \%$ of users liked the park, $5 \%$ did not like the park, $80 \%$ wanted to visit the park again, $15 \%$ did not want to visit again and expectations of $85 \%$ were met (Table 9). 
Table 9. General satisfaction of users

\begin{tabular}{|c|c|c|c|}
\hline \multicolumn{4}{|c|}{ Do you like this park? } \\
\hline Variables & $\begin{array}{l}\text { Percent } \\
(\%)\end{array}$ & Variables & $\begin{array}{l}\text { Percent } \\
(\%)\end{array}$ \\
\hline Yes & 90 & Almost & 3 \\
\hline No & 5 & No opinion & 2 \\
\hline \multicolumn{4}{|c|}{ Would you like to go to this park again? } \\
\hline Variables & $\begin{array}{l}\text { Percent } \\
(\%)\end{array}$ & Variables & $\begin{array}{l}\text { Percent } \\
(\%)\end{array}$ \\
\hline Yes & 80 & Almost & 4 \\
\hline No & 15 & No opinion & 1 \\
\hline \multicolumn{4}{|c|}{ Did this park meet your expectations? } \\
\hline Variables & $\begin{array}{c}\text { Percent } \\
(\%)\end{array}$ & Variables & $\begin{array}{c}\text { Percent } \\
(\%)\end{array}$ \\
\hline Yes & 85 & Almost & 3 \\
\hline No & 10 & No opinion & 2 \\
\hline
\end{tabular}

When problems related with the park were questioned, "lack of car park" 53\%, "park's being crowded" 25\%, "cars parked on roads" $15 \%$ were the results with the highest rates. Park's transportation problem was evaluated by $83 \%$ as "no". Access to park was done by $45 \%$ "on foot" (Table 10).

Table 10. Evaluation of park problems

\begin{tabular}{|c|c|c|c|}
\hline \multicolumn{4}{|c|}{ What are the problems in this park? } \\
\hline Variables & $\begin{array}{c}\text { Percent } \\
(\%)\end{array}$ & Variables & $\begin{array}{l}\text { Percent } \\
(\%)\end{array}$ \\
\hline Lack of parking & 53 & $\begin{array}{l}\text { Heavy traffic and } \\
\text { vehicle noise }\end{array}$ & 55 \\
\hline $\begin{array}{l}\text { The park is } \\
\text { crowded }\end{array}$ & 25 & $\begin{array}{l}\text { Inadequacy of } \\
\text { furniture }\end{array}$ & 4 \\
\hline Parking on roads & 8 & $\begin{array}{l}\text { Lack of toilet- } \\
\text { fountain-bin }\end{array}$ & 5 \\
\hline \multicolumn{4}{|c|}{ Is there any transportation problem in this park? } \\
\hline Variables & $\begin{array}{c}\text { Percent } \\
(\%)\end{array}$ & Variables & $\begin{array}{l}\text { Percent } \\
(\%)\end{array}$ \\
\hline Yes & 11 & Almost & 6 \\
\hline No & 83 & No opinion & - \\
\hline \multicolumn{4}{|c|}{ How do you provide access to this park? } \\
\hline Variables & $\begin{array}{c}\text { Percent } \\
(\%)\end{array}$ & Variables & $\begin{array}{l}\text { Percent } \\
(\%)\end{array}$ \\
\hline On foot & 45 & Private vehicle & 22 \\
\hline $\begin{array}{l}\text { Public } \\
\text { transportation }\end{array}$ & 31 & Bicycle & 2 \\
\hline Motorcycle & - & & \\
\hline
\end{tabular}

\section{Conclusion and discussion}

This study, examining influences between space quality of urban parks and user satisfaction, focused on "EYOF
Memory Park" in Trabzon city center which was built in scope of urban improvement. As previous neglected and non-functional condition of the park area did not have appropriate facilities, landscape design project was carried for the area. Considering growth of the city and increasing need for green areas, the area was reserved for use of citizens as an urban park. Space quality of the park and influences of this quality on user satisfaction were investigated. Many studies support the opinion that high space quality is very well correlated with higher user satisfaction (Lynch, 1973; Rapoport, 1977; Gibson, 1979; PPS, 2005; Gehl, 1987; İnceoğlu \& Aytuğ, 2009; Uzgören \& Erdönmez, 2007; Gürer \& Uğurlar, 2017). As it is stated by Lynch (1973) and Gehl (1987) increase in space quality has positive effects on variety and period of urban area activities, comfort, preferability and quality of the area.

Furthermore, it was observed that users visit the park in order to enjoy the concept and take photographs. Turkish and Japanese cultural traces of the park created awareness and attractiveness for visitors. It was clear that memorability, beauty and recreative facilities were related to landscape design concept of the park. It was observed that landscape design elements such as texture, color, size and shape were the most effective parameters in representing the overall design. It was because of appropriate and professional usage to create high quality spaces by landscape designers of the park. Plant variety, water element, rock gardens and texture and color characteristics of structural elements increased visual quality of the area and created effective compositions. Similar studies reported that green texture with surrounding water elements could increase the visual effects (Özgeriş \& Karahan, 2015). Even though the study area was flat, structural elements and diverse floral design used in the area improved space quality by adding dynamism. This is also reported by some other studies (Hunziker \& Kienast, 1999).

It was determined that accessibility, feeling of safety and peace, and recreational facilities increased user satisfaction. On the other hand, heavy traffic, lack of car park and crowd had negative effects on users. Similar results were reported by Uzun (2005) and Uzun and Müdessiroğlu's (2010). Today urbanization and loss of green areas detract people away from natural areas and possibility of meeting recreational needs decreases. Busy urban life direct citizens to accessible green areas in short distances with facilities for physical activity and relaxing. That is why accessibility is among the most important factors effecting user satisfaction (Gökyer \& Bilgili, 2014). Findings of the study also indicated that accessibility of the park contributes to its preferability. It is determined that most of the users came from the close vicinity of the park (Kalkınma Neighborhood, Bostancı and University Neighborhoods) by walking or public transportation. Visitors with private cars generally came from distant districts. It was also determined that accessing park by walking was a satisfying factor for users. Moreover the park was rated with high scores in terms of safety. That is because of the fact that 
it is very well isolated from nearby international highway. Feeling of safety is one of the factors effecting user satisfaction positively (Çayır, 2004). Especially there are many studies supporting that recreational facilities are effective on area usage choices. The study reached similar results with the literature on this context too (Müderrisoğlu et al., 2005).

High level of general satisfaction in visual quality studies is directly related with sufficient facilities and well keeping level of the park. Many studies indicated that well-kept areas were more preferred than neglected areas (Aytaş \& Uzun, 2015; Güneroğlu, 2017).

Urban environments should be designed with the slogan of "Design for Everybody" and they should address all segments of the society. They should especially be formed in a richness which can prepare a basis for urban recreational facilities and social interaction, and offer people different living areas. Rising life quality and increasing sense of belonging to the city depend on design quality of the open green spaces or urban parks. Besides, it should be noted that urban parks are strategic areas which increase quality of life, empower identity of cities, and create benefits for the city on aesthetic, ecologic, economic and recreational contexts.

Landscape studies produce designs effecting visual taste of people. Visual taste is very important for users' preferences. Preference rate of an area is directly proportional to its beauty, impressiveness, being well-kept and memorable properties. Thus, it is important to ensure both aesthetic and functional usage in landscape design projects.

In conclusion, it can be stated that, this study, which started with the assumption that space quality of EYOF Park can provide user satisfaction, evaluated current satisfaction level and expectations of users and indicated that increase of space quality of urban parks adds high value to the city. This study can be used as a reference for future researches on space design in landscape architecture.

\section{References}

Aytaş, İ., \& Uzun, S. (2015). Determining visual landscape quality of pedestrian areas in Düzce city center. Journal of the Faculty of Forestry Istanbul University, 65(1), 11-29. https://doi.org/10.17099/jffiu.60910

Bahriny, F., \& Bell, S. (2020). Patterns of urban park use and their relationship to factors of quality: A case study of Tehran, Iran. Sustainability, 12(4), 1560.

https://doi.org/10.3390/su12041560

Bayramoğlu, N. (2010). Urban identity in the context of users perception: Barbaros Boulevard-Büyükdere street urban axis [Master's thesis]. Istanbul Technical University, Institute of Science and Technology.

Carmona, M., Heath T., Oc, T., \& Tiesdell, S. (2003). Public places urban spaces. Architectural Press.

Central Park Conservancy. (2018). Central park conservancy/ About us. https://www.centralparknyc.org/about

Çayır, A. S. (2004). Users evaluation of green areas in beyoglu: Example of Gümüsssuyu, Sururi and Hasköy Parks [Master's thesis]. Istanbul Technical University, Institute of Science and Technology.

Dihkan, M., Güneroğlu, N., Güneroğlu, A., \& Karslı, F. (2017). The need for ecosystem-based coastal planning in Trabzon City. International Journal of Environment and Geoinformatics, 4(3), 193-205. https://doi.org/10.30897/ijegeo.348791

Gehl, J. (1987). Life between buildings: Using public space. Van Nostrand Reinhold.

Gehl, J. (2010). Cities for people. Island Press.

Gehl, J., \& Gemzøe, L. (2001). New city spaces. Danish Architectural Press.

George, D., \& Mallery, P. (2020). IBM SPSS statistics 26 step by step: A simple guide and reference. Routledge.

https://doi.org/10.4324/9780429056765

Gibson, J. J. (1979). The ecological approach to visual perception. Psychology Press.

Gökyer, E., \& Bilgili, B. (2014). A research on assessment of accessibility of green areas: The case of Bartın province. SDU Faculty of Forestry Journal, 15(2), 140-147.

Güneroğlu, N. (2017). The effect of restoration process on riparian landscapes. Artvin Coruh University Journal of Forestry Faculty, 18(1), 10-20.

Gürer, N., \& Uğurlar, A. (2017). User satisfaction in urban parks: Ankara Kuğulu park case. Megaron, 12(3), 443-459. https://doi.org/10.5505/megaron.2017.76094

Hayta, Y., \& Altan, Y. (2016). Urban life perceptions and changing urban life styles: İzmir example. The Journal of Academic Social Science, 4(33), 223-258. https://doi.org/10.16992/ ASOS.3460

Herrington, S. (2015). Fraternally yours: The union architecture of Oskar Stonorov and Walter Reuther. Social History, 40(3), 360-384. https://doi.org/10.1080/03071022.2015.1043189

Huot, J. L., Thalmann, J. P., Valbelle, D., \& Girgin, A. B. (2000). The birth of cities. Imge Publishing.

Hunziker, M., \& Kienast, F. (1999). Potential impacts of changing agricultural activities on scenic beauty - a prototypical technique for automated rapid assessment. Landscape Ecology, 14(2), 161-176. https://doi.org/10.1023/A:1008079715913

İnceoğlu, M., \& Aytuğ, A. (2009). The concept of urban space quality. Megaron, 4(3), 131-146.

Jahani, A., \& Saffariha, M. (2020). Aesthetic preference and mental restoration prediction in urban parks: An application of environmental modeling approach. Urban Forestry \& Urban Greening, 54, 126775.

https://doi.org/10.1016/j.ufug.2020.126775

Karakurt, E. (2006). Suggestions for organizing urban space: Modern urban planning understanding and postmodern urban planning understanding. Erciyes University Journal of Faculty of Economics and Administrative Sciences, 26, 1-25.

Liu, C., Qi, T., \& Ma, X. (2016). The research on the impact assessment of visual landscape of country parks in Beijing. Journal of Environmental Engineering and Landscape Management, 24(1), 37-47. https://doi.org/10.3846/16486897.2015.1106545

Lynch, K. (1973). The image of the city. MIT Press.

Müderrisoğlu, H., Yerli, Ö., Turan, A. A., \& Duru, N. (2005). Determination of user satisfaction in Abant nature park by using ROS method. Journal of Agricultural Sciences, 11(4), 397-405.

Ostoić, S. K., van den Bosch, C. C. K., Vuletić, D., Stevanov, M., Živojinović, I., Mutabdžija-Bećirović, S., Lazarevic, J., Stojanova, B., Blagojevic, D., Stojanovska, M., Nevenic, R., \& Malovrh, Š. P. (2017). Citizens' perception of and satisfaction with urban forests and green space: Results from selected 
Southeast European cities. Urban Forestry \& Urban Greening, 23, 93-103. https://doi.org/10.1016/j.ufug.2017.02.005

Özgeriş, M., \& Karahan, F. (2015). A study on visual quality assessment in recreational facilities: Sample of Tortum and Uzundere (Erzurum). Artvin Coruh University Journal of Forestry Faculty, 16(1), 40-49.

Polat, A. T., \& Akay, A. (2015). Relationships between the visual preferences of urban recreation area users and various landscape design elements. Urban Forestry \& Urban Greening, 14(3), 573-582. https://doi.org/10.1016/j.ufug.2015.05.009

Project for Public Spaces. (2005). What makes a place great. https://www.pps.org/article/august2005whatmakesplacegreat

Rapoport, A. (1977). Human aspects of urban form: Towards a man - environment approach to urban form and design. Pergamon Press.

San Francisco Recreation and Parks. (2018). Discover Golden Gate Park. http://sfrecpark.org/parks-open-spaces/goldengate-park-guide/

Şahan, M. (2016). Review on relationship between sculpture and environment in urban area. Anadolu University Journal of Art \& Design, 6(2), 92-109. https://doi.org/10.20488/www-std-anadolu-edu-tr.292706

Santos, T., Mendes, R. N., \& Vasco, A. (2016). Recreational activities in urban parks: Spatial interactions among users. Journal of Outdoor Recreation and Tourism, 15, 1-9. https://doi.org/10.1016/j.jort.2016.06.001

Topal, A. K. (2004). What is the conceptual of city and where is the city in Turkey? Dokuz Eylul University the Journal of Graduate School of Social Sciences, 6(1), 276-294.
Ülkeryıldız, R. E. (2009). Political tactics in building construction industry from the architects' perspectives [Master's thesis]. İzmir Institute of Technology.

Uzgören, G., \& Erdönmez, M. E. (2017). A comparative study on the relationship between the quality of space and urban activities in the public open spaces. Megaron, 12(1), 41-56.

Uzun, S. (2005). User satisfaction on rural and urban parks; the example of Gölcük rural recreation area and İnönü park [Master's thesis]. Abant İzzet Baysal University, Institute of Science and Technology.

Uzun, S., \& Müderrisoğlu, H. (2010). User satisfaction in rural recreation areas: The example of Bolu Gölcük forest-recreation area. SDU Faculty of Forestry Journal, 11(1), 67-82.

Vondel Park. (2018). World's 20 largest city parks "Vondelpark". https://listelist.com/dunyanin-en-buyuk-20-sehir-parki/

Wey, W. M., \& Wei, W. L. (2016). Urban street environment design for quality of urban life. Social Indicators Research, 126(1), 161-186. https://doi.org/10.1007/s11205-015-0880-2

Wolch, J. R., Byrne, J., \& Newell, J. P. (2014). Urban green space, public health, and environmental justice: The challenge of making cities "just green enough". Landscape and Urban Planning, 125, 234-244.

https://doi.org/10.1016/j.landurbplan.2014.01.017

Zhang, S., \& Zhou, W. (2018). Recreational visits to urban parks and factors affecting park visits: Evidence from geotagged social media data. Landscape and Urban Planning, 180, 27-35. https://doi.org/10.1016/j.landurbplan.2018.08.004 